\title{
Determinant Factors of the Household Poverty Probability: Study on Household around the Taman Nasional Kerinci Sebelat (TNKS) Lebong Regency
}

\author{
Gustin Rizki Utariyanto, Ketut Sukiyono*, and Septri Widiono \\ Department of Agricultural Socio-Economic, Faculty of Agriculture University of Bengkulu \\ *Email. ksukiyono@unib.ac.id
}

\begin{abstract}
This research aims to determine the factors that influence the probability of occurrence of poverty of households around Taman Nasional Kerinci Seblat (Kerinci Sebelat National Park (TNKS) Lebong District. The location of this research selected purposively by categorizing the 6 villages into 3 typologies, namely, Sawah dominance, plantation Dominance, and rice fields and plantation. From each village, 20 households as respondents were selected randomly, so the total respondents were 120 households. Sayogjo poverty line was applied to determine household poverty status. In examining the factors that affect the probability of the household poverty, a logit model is applied. From the analysis, land area ownership is the main factor influencing the occurrence probability of poverty of households, while education level, number of family dependents, and household head age are not.
\end{abstract}

Keywords : Probability, Poverty, logit model

Reference to this paper should be made as follows :

Utariyanto, G. R., K. Sukiyono, and S. Widiono. 2020. Determinant Factors of the Household Poverty

Probability: Study on Household around the Taman Nasional Kerinci Sebelat (TNKS) Lebong

Regency. Agritropica: Journal of Agricultural Sciences. 3 (1): 29-37. Doi:

https:// doi.org/10.31186/Jagritropica.3.1.29-37

\section{INTRODUCTION}

One of the goals of national development is to improve economic performance to create jobs and organize decent lives, which in turn will bring prosperity to the Indonesian. This goal can be achieved through poverty reduction. The problem of poverty is indeed complex and multidimensional. Therefore, efforts to reduce poverty must be carried out comprehensively, cover various aspects of community life, and be implemented in an integrated manner (Nasir et al, 2008).

Data published by BPS informed that Bengkulu's latest poverty rate as of September 2018 was recorded at $15.41 \%$, a slight decrease compared to the same period the previous year at $15.59 \%$. Although in terms of the percentage of the number of poor people in Lebong Regency is relatively small compared to districts and cities in
Bengkulu Province, data published by BPS Lebong Regency shows an increase in the number of poor people in 2018 (BPS, 2018) Among these poor households, some of them live in the residents around the forest, specifically the Kerinci Seblat National Park (TNKS). Communities living around forests are one of the largest poor groups and this tends to be chronic. Various factors, such as lack of infrastructure, difficulty in communication, forest distance from markets, health facilities, and education, are often considered as the cause of their poverty. As a result, it is very difficult to eradicate the poverty experienced them. Meanwhile, the existence of forests becomes absolute for the fulfillment of food, buildings, water supply providers, and others that are fundamental to the poorest households living around the forest. From the government side, poverty alleviation 
policies are mostly based on non-forest villages and ineffective programs because the information is not up to remote areas (Anonim, 2009).

Poverty is a situation of inadequacy that occurs not because the poor want it, but because it cannot be avoided with the powerthat is in it. Poverty can be interpreted broadly as moral poverty, scientific poverty, and material poverty. To simplify, poverty is indicated by the low level of income to meet the minimum living needs. Low income will result in a low reach of food so that it can result in low nutritional and health status. Low nutritional and health status results in intelligence, education, and skills which results in low work productivity which in turn results in low income (Kartasasmita, 1997). Many approaches are used in determining the poor population. Poverty is often evaluated and measured by income or expenditure and used to determine households that are poor or not. This approach has become the standard indicator to measure poverty and living standards quantitatively (Ayinde et al., (2002); Baiyegunhi \& Fraser (2010); Achial et al., 2010; Akerele, et al, 2012). In Indonesia, one of the poverty approaches is the poverty approach as suggested by Sajogyo (1987). Sajogyo (1987), revealed that poverty is a level of life under the minimum standard of living that is determined on staple food needs that make people sufficient in working and healthy. Sajogyo in determining the poverty line uses the equivalent of per capita rice consumption. Rice consumption for urban and rural areas is determined at $360 \mathrm{~kg}$ and $240 \mathrm{~kg}$ per capita per year, respectively. This approach was also used by Wiyanto, Sukiyono, \& Priyono (2014) to measure poverty among Horticultural Farmers in Rejang Lebong District.

Several studies have tried to analyze the relationship between household demographic variables and poverty. According to Amar (2002), poverty is relatively visible from the inequality of ownership of production assets, especially land as agricultural land and the unequal distribution of income between community groups. Even distribution of land tenure will greatly affect the distribution of community income because the land is the main production factor for the community in creating family income. Also, research Cahyono et al, (2006), for example, have tried to link the variables of household income, the number of household members, the age of the head of the household with the Poverty of Pennant Sap Farmers. While research by Sa'diyah (2012) and Suryawati (2005) examines the relationship between the number of family dependents, the level of education and asset ownership and poverty. Other researches have also examined socio-economic determinant, among others, are Baiyegunhi \& Fraser (2010) in South Africa; Akarele (2011) in Nigeria; Akerele et al, (2012) in South-West Nigeria; and Gounder (2013) in Fiji. In general, they concluded that household socioeconomic conditions correlated with household poverty.

Departing from the discussion above, this study aims to measure poverty levels and determine the factors that influence the probability of poverty occurring in households living around TNKS.

\section{MATERIALS AND METHODS}

The location of this study was chosen purposively, i.e., Lebong Regency. In this study, the classification of villages is divided into 3 (three) typologies, namely typology of Sawah dominance (food crops), typology of plantations dominance (coffee and rubber), and typology of combined sawah and plantation. The six villages can be seen in Table 2.

\section{Data Analysis Method}

To analyze the probability factors for household poverty around the TNKS, households are grouped into two categories, namely poor and not poor. The determination of these categories is based on household income converted into rice exchange rates. Households that have income per capita less than the exchange 
rate of $320 \mathrm{~kg}$ of rice per year or $26.67 \mathrm{~kg}$ of rice per month are categorized as low

Table 1. Research area and number of samples

\begin{tabular}{|c|c|c|c|c|}
\hline No & District & Village & Typology & Samples \\
\hline 1 & \multirow{2}{*}{ Embong Uram } & Ujung Tanjung II & \multirow{2}{*}{ Sawah Dominance } & 20 \\
\hline 2 & & Kota Baru & & 20 \\
\hline 3 & \multirow{2}{*}{ Topos } & Talang Donok & \multirow{2}{*}{ Plantation Dominance } & 20 \\
\hline 4 & & Talang Baru & & 20 \\
\hline 5 & \multirow{2}{*}{ Bingin Kuning } & Karang Dapo Atas & Combined Sawah and & 20 \\
\hline 6 & & Talang Leak I & Plantation & 20 \\
\hline
\end{tabular}

From each village, 20 households were selected randomly (simple random sampling), so that a total of 120 respondents.

economic (poor) following Sayogjo (1987). The households that have income greater or equal to the exchange rate of $320 \mathrm{~kg}$ of rice per year or $26.67 \mathrm{~kg}$ of rice per month are categorized as households with high socioeconomic status (not poor).

In determining the factors that affect the probability of occurrence of household poverty around TNKS, a binary choice model, or a linear probability model (Gujarati, 1978) in logit form is applied. The logit model is a non-linear regression model that produces an equation where the dependent variable is categorical. The most basic category of the logit model has binary

$$
p_{i}=\frac{1}{1+e^{\beta_{1}+\beta_{2} X_{1}}}
$$

Let $Z_{i}=\beta_{1}+\beta_{2} X_{i}$, then $p_{i}=\frac{1}{1+e^{-Z_{i 1}}}=F\left(\beta_{i}+\beta_{2} X_{i}\right)=F\left(Z_{i}\right)$, where $Z_{i}$ ranges from $-\infty$ to $\infty, P_{i}$ ranges between 0 and 1 ; and $P_{i}$ is non-linearly related to $Z_{i}$.

It should be noted that

$$
e^{Z_{i}}=\frac{p_{i}}{\left(1-p_{i}\right)} \text {, so } \ln \left(\frac{p_{i}}{\left(1-p_{i}\right)}\right)=Z_{i}=\beta_{i}+\beta_{2} X_{i}
$$

Empirically, household poverty is assumed to be a function of the age of the head of the household (SIZE), the number of household members (SIZE), the area of land ownership (AREA), and the level of

education of the head of the household (EDU). Thus, the logit model for the poverty of households living around TNKS is as follows:

$$
\ln \left(\frac{p_{i}}{\left(1-p_{i}\right)}\right)=\beta_{1}+\beta_{2} A G E_{t}+\beta_{2} S I Z E_{t}+\beta_{4} A R E A_{t}+\beta_{5} E D U_{t}+\mu_{t}
$$




\section{RESULTS AND DISCUSSION}

\section{Characteristics of Respondents}

Respondents at the research location are characterized by diverse characteristics in terms of the level of education, and the number of family dependents. Age is an important factor in farming activities because age is related to the enthusiasm and productivity of farmers. The age of respondents based on data from the field ranged from 22 years to 70 years with an average age of respondents 45.29 years. Based on Table 2, it can be seen that the largest percentage of the age of farmers is 39 years to 55 years with $48.33 \%$. It is, then, followed by the age range of 22 years to 38 years, i.e., $31.67 \%$ and the age range of 56 years to 70 years, i.e., $20.00 \%$.

Table 2. Characteristics of Households

\begin{tabular}{|c|c|c|c|}
\hline Description & $\begin{array}{l}\text { Frequency } \\
\text { (Person) }\end{array}$ & $\begin{array}{l}\text { Percentage } \\
(\%)\end{array}$ & Mean \\
\hline \multicolumn{4}{|l|}{ Age (year) } \\
\hline . $22-38$ & 38 & 31.67 & \multirow{3}{*}{45.29} \\
\hline - $39-55$ & 58 & 48.33 & \\
\hline - $56-70$ & 24 & 20.00 & \\
\hline \multicolumn{4}{|c|}{ Number of family dependents (person) } \\
\hline - $2-3$ & 53 & 44.67 & \multirow{3}{*}{3.88} \\
\hline - $4-5$ & 58 & 48.33 & \\
\hline - $6-7$ & 9 & 7.50 & \\
\hline \multicolumn{4}{|l|}{ Land area $(\mathrm{Ha})$} \\
\hline - $0.25-1.83$ & 90 & 75.00 & \multirow{3}{*}{1.33} \\
\hline - $1.84-3.42$ & 27 & 22.50 & \\
\hline - $3.43-5.00$ & 3 & 2.50 & \\
\hline \multicolumn{4}{|l|}{ Education(year) } \\
\hline - $3-6$ & 62 & 51.67 & \multirow{3}{*}{7.90} \\
\hline - $7-9$ & 37 & 30.83 & \\
\hline - $10-12$ & 21 & 17.50 & \\
\hline \multicolumn{4}{|l|}{ Income (IDR) } \\
\hline - $\quad 225,000.00-4,258,333.33$ & 117 & 97.50 & \multirow{3}{*}{$1,442,934.03$} \\
\hline - $4,258,333.34-8,741,666.67$ & & 1.67 & \\
\hline - $8,516,666.68-13,000,000.00$ & & 0,83 & \\
\hline
\end{tabular}

Looking at the farmers' age, farmers in the research area are classified as productive age, where at this age a person has a better ability to think and act in planing an activity. This is in line with the opinion of Simanjuntak (1998), which states that the ages 15 to 65 years are productive. Thus, all farmers who are in the range of 3955 years of age are productive age groups, meaning that at this productive age all abilities can be optimized and can run their businesses.

The number of dependents is a household member who is the responsibility of the head of the family and lives in the same house. To meet the family's living needs, farmers must work and try to improve farming optimally. In the study area family dependents range from 2 people to 7 people and the average farmer has a family responsibility of 3.88 or 4 people.

Table 2 shows that most households have family dependents between 4 - 5 persons with $48.33 \%$ of the total respondents. The number of family dependents is a family member whose living expenses are still borne by the family. Family members such as wives, children, parents, or other relatives who usually motivate the head of the family to work harder in the hope that they can 
meet the needs of family life. The number of family dependents are very closely related to the large economic burden borne by farmers, the greater the number of family dependents, the greater the costs to meet family needs. But indirectly can motivate farmers to produce optimal production. Also, the more the number of dependents of productive-aged families, the more workers will be able to assist in farming activities to reduce the costs incurred for labor costs.

The area of land owned by farmers also affects the income earned. The greater the land area, the more production is generated in paralel with their income. All land areas are owned and managed by the farmers themselves. The land area ownership ranges from 0.25 to 5.00 ha with average land ownership of 1.33 ha. Based on research, most farmers own land between 0.25 ha - 1.83 ha with average land ownership of 1.33 ha. Only a small proportion of farmers own ranged more than 1.84 ha of land.

One important factor determines farmer success in their farming activities is education, especially formal education. Education can determine a person's ability to adopt innovations. Based on Table 2, farmer education ranges from 6 years to 12 years with an average education level of 7.90 years. This table also shows that the majority of farmers have the lowest level of formal education, which is between $3-6$ years. The number reaches $52 \%$ of the total population. This condition is common in the agricultural sector in Indonesia and this condition often becomes an obstacle in the application of new technology, especially relating to agriculture and conservation.
Income is the sum of all revenues of both farm and non-farm revenues. Income is very important to meet the needs of household life, especially daily household needs. Income is often considered as a determinant of the level of household welfare because the size of the income will determine whether the needs of the household are met or not. The smaller the income the more difficult it is to meet every day. Table 2 shows the level of farmer acceptance ranging from IDR 225,000.00 to IDR 13,000,000.00. Farmers who have low income are 117 people or $97.50 \%$, farmers who have medium income are 2 people or $1.67 \%$, and farmers who have a high income are 1 person or $0.83 \%$ with an average farmer income of Rp. 1,442,934.03.

\section{Household Poverty Status}

In this study, the determination of criteria for poor and non-poor households is seen from household income which is a proxy of expenditure, as Sajogyo (1987) suggested. Households that have income per capita less than the exchange rate of $320 \mathrm{~kg}$ of rice per year or $26.67 \mathrm{~kg}$ of rice per month are categorized as low economic (poor). The households that have a greater or equal income with an exchange rate of $320 \mathrm{~kg}$ of rice per year or $26.67 \mathrm{~kg}$ of rice per month are categorized as households with high socioeconomic status (not poor). The distribution of households based on their poverty status is presented in Table 3 .

Table 3 shows the status of poor households and non-poor households in each district. This table shows that $26.67 \%$ of households are categorized as poor households spread over three districts. On the other hand, the number of households classified as not poor is $73.33 \%$ of

Table 3. Household distribution based on their poverty status

\begin{tabular}{lllll}
\hline \multirow{2}{*}{ Subdistrict } & \multicolumn{2}{l}{ Poor Household } & \multicolumn{2}{l}{ Not -Poor Household } \\
\cline { 2 - 5 } & Number $(\mathrm{HH})$ & Persentage $(\%)$ & Number $(\mathrm{HH})$ & Persentage $(\%)$ \\
\hline Embong Uram & 16 & 13.34 & 24 & 20.00 \\
Topos & 9 & 7.50 & 31 & 25.83 \\
Bingin Kuning & 7 & 5.83 & 33 & 27.50 \\
Total & 32 & 26.67 & 88 & 73.33 \\
\hline
\end{tabular}


the total number of households. These results indicate that households living around TNKS belong to households that are economically sufficient to meet their daily needs. However, it should be noted that poverty studies not only improve the welfare of households that are currently poor but also prevent households from becoming poor in the future. Therefore, new future perspectives must be adopted and implemented. This is important because the households living in vulnerable condition.. For this reason, suitable forward-looking anti-poverty interventions need to be considered. This intervention must be oriented towards preventing poverty in the future rather than reducing poverty today.
Determinant Factors of Household Poverty

The results of the logit model estimation as revealed in the research method are presented in Table 4. Result analysis shows that all variables in the model, namely AGE, SIZE, AREA, and EDU, jointly affect the occurrence of household poverty. This conclusion is based on F-test results where $F_{\text {statistic }}(5.91)$ is greater than $\mathrm{F}_{\text {table }}(2.45)$ at a $95 \%$ confidence level. All variables are also able to explain household poverty variation of $51.72 \%$ as shown by the $\mathrm{R}^{2}$ value of 0.517 . The remaining $48.28 \%$ is influenced by other factors not included in the model, such as infrastructure access. The effect of each of the variables in the model on household poverty will be explained as follows:

Table 4. Estimated Results of the Logit model

\begin{tabular}{llll}
\hline Independent Variable & $\begin{array}{l}\text { Regression } \\
\text { Coefficient }\left(\beta_{i}\right)\end{array}$ & $\begin{array}{l}\text { Standard } \\
\text { Error }\end{array}$ & \multirow{2}{*}{$\mathrm{t}_{\text {statistic }}$} \\
\hline Household Head Age (AGE) & -0.30123 & 0.19118 & -0.15757 \\
Number of Family Dependents (SIZE) & 0.16764 & 0.20284 & 0.82649 \\
Land area ownership (AREA) & -0.68817 & 0.32881 & $-2.0929^{*}$ \\
Household Head Education (EDU) & -0.36532 & 0.90562 & -0.40339 \\
Constant & -0.36509 & & \\
$\mathrm{R}^{2}$ & 0.51727 & & \\
$\mathrm{t}_{\text {table }}$ & 1.980 & & \\
$\mathrm{~F}_{\text {table }}$ & 2.45 & & \\
$\mathrm{~F}_{\text {statistic }}$ & 0.59108 & & \\
\hline Note $\left.{ }^{*}\right)=$ significant at 95\% & & & \\
\hline
\end{tabular}

\section{Household Head Age (AGE)}

Estimation results show that age does not significantly affect the probability of occurrence of household poverty. Using a statistical t-test on the AGE coefficient, it shows that its $t_{\text {statistic }}(-0.15757)$ is smaller than $t_{\text {table }}(1,980)$. This result concludes that the nil hypothesis is accepted and informs that age does not affect the probability of occurrence of household poverty. The results of this study contradict the research conducted by Cahyono (2006), showing that households classified as poor are at a relatively old age so that it is relatively more difficult to increase their incomes. In addition, with age, the burden on household dependents is greater. This condition results in higher probabilities to be poor for the aged.

\section{Number of family dependents (SIZE)}

The estimation results show that the number of family dependents has also an insignificant effect on the probability of occurrence of household poverty, as indicated by the results of the t-test. Although contrary in theory, the finding is consistent with research conducted by Sa'diyah (2012) and Noor (2005). They concluded that the relationship between the number of family members and household poverty is insignificant and has a negative sign. The number of family members should be a significant factor to influence household 
poverty because the larger number of members will be a burden on a household and affect the productivity of the household head. Furthermore, Noor explained that the more the number of family members, the smaller the income per capita and the poorer the family. The number of family members in the community studied tends to be large because it is related to the strength of the family kinship system, especially in the village. The house is big and spacious so that all of his children, who are married even though they live together. However, Wiyanto, Sukiyono \& Priyono (2014) research found the opposite results. They found that the number of dependents of the farmer's family had a significant effect on the probability of poverty occurring of vegetable farmers. This finding is also similar to research in Nigeria as conducted by Akerele (2011) and Akerele, et al (2012) where the number of dependents becomes a determinant of household poverty.

\section{Land Ownership Area (AREA)}

A statistical t-test on the AREA variable shows that the value of $t_{\text {statistic }}$ ($2.0929)$ is greater than the $t$-table $(1,980)$. This Estimation results show that the area of land ownership has a significant and negative effect on the probability of occurrence of household poverty. The results of this study are consistent with research conducted by Sa'diyah (2012); Akerele, et al (2012) and Wiyanto, Sukiyono, \& Priyono (2014), showing that capital ownership (assets) has a negative effect on poverty. This means that the smaller the capital owned by the community, the smaller the per capita income of the people studied, means that the quality of life is getting poorer. According to Amar (2002), poverty is relatively visible from the inequality of ownership of production assets, especially land as agricultural land and the unequal distribution of income between community groups. Distribution of land tenure will greatly affects the distribution of community income. The main reason is that land is the main production factor for the household to generate family income.

\section{Education (EDU)}

Estimation results show that formal education does not significantly affect the probability of occurrence of household poverty as indicated by $\mathrm{t}$-test results on the EDU variable. As presented in Table 4, the $t_{\text {statistic }}$ value of EDU is smaller than the value of $t_{\text {table, }}$ i.e., $-0.40339<1,980$ at a $95 \%$ confidence level. This finding is similar to Amar (2002). He found that education at various levels does not show a significant effect on poverty. The insignificance of levels of education on poverty provides a piece of evidence that the level of education in rural areas does not determine household income as well as the household elimination from poverty. However, this finding differs from Sa'diyah (2012); Akerele, et al (2012); and Gounder (2013) finding. They found that that there was a positive relationship between the household head education level household heads and household poverty. A household with a lower head of education level, it tends to be poor than the household head with a higher level of education.

\section{Marjinal Effect}

The interpretation of the logit regression model can be accomplished based on marginal effects. Marginal effects in this study to examine changes in AGE, SIZE, AREA, and EDU on the possibility of poverty in households living around TNKS. Table 5 presents the results of the estimated marginal effects of independent variables on the occurrence of poverty on households. 
Tabel 7. Marginal Effects of Independent Variables on the Probability of Poverty on Households

\begin{tabular}{lll}
\hline No & Independent Variable & Marginal effect \\
\hline 1 & Household Head Age (AGE) & -0.57739 \\
2 & Number of Family Dependents (SIZE) & 0.32133 \\
3 & Land area ownership (AREA) & -0.13191 \\
4 & Household Head Education (EDU) & -0.70023 \\
\hline
\end{tabular}

From Table 7 it can be seen that the four variables have a contribution that can reduce the occurrence of household poverty. From the estimated results of the marginal effect of the land area variable also has the effect of reducing the chances of households experiencing poverty. Households that have a large area of land will have a probability of $(-0.13191)$ not to experience poverty compared to households that have narrow land. The greater the area of land, the more production is produced which will automatically increase income which can reduce the chances of poverty in the household.

\section{CONCLUSIONS RECOMMENDATIONS}

AND

Based on the results of the study, it can be concluded that; the factors that influence the occurrence of the household poverty probability around the Kerinci National Park in Lebong Regency are the area of land ownership, while the age, number of family dependents and education have no significant effect on the occurrence of the household poverty probability.

Based on the research results obtained, it is suggested to the Government to provide access to the community through programs of improvement and coaching as well as access for the poor through counseling activities, skills training, and human resource improvement which are expected to help households around the Park area National Kerinci Sebelat (TNKS) Lebong Regency in terms of the application of innovations/technologies to increase farm productivity and reduce household poverty.

\section{REFERENCES}

Achial, T. N.O., Wangombe, A. and Khadioli, N. (2010), A logistic regression model to identify key determinants of poverty using economic and health survey data, European Journal of Social Sciences, 13(1): 3845

Akerele, Dare, Siaka Momoh, Samuel A. Adewuyi, Biola B. Phillip, \& Olumuyiwa F. Ashaolu, (2012) Socioeconomic determinants of poverty among urban households in South-West Nigeria, International Journal of Social Economics, 39(3): 168 - 181. http:/ / dx.doi.org/10.1108/0306829 1211199341

Akerele, D. (2011), Analysis of poverty profiles and socioeconomic determinants of welfare among urban household in Ekiti State, Nigeria, Current Research Journal of Social Sciences, 3(1): 1-7.

Amar, Syamsul.2002. Kajian Ekonomi Tentang Kemiskinan di Pedesaan Propinsi Sumatera Barat. Jurnal Ekonomi Pembangunan Kajian Ekonomi Negara Berkembang. Vol. 7, No. 2, h: 107111.http://journal.uii.ac.id/index.p hp/JEP/article/viewFile/644/572. Diunduh 18 Oktober 2014

Anonim $^{1}$. 2009. Identifikasi potensi ekonomi di pedesaan. (http//:www.bahanajar-analisis-potensi-ekonomidesa.com). Diakses 25 Agustus 2013. 
Ayinde, I. A., Afolami, C.A., Aromolaran, A.B., Vaughan, I.O., and Fanimo, A.O. (2002), Intra-zonal poverty situation among farmers in Ogun State, Nigeria, Moor Journal of Agricultural Research, 3(2): 306-12.

Badan Pusat Statistik. 2012. Kabupaten Lebong Dalam Angka 2012. BPS Provinsi Bengkulu. Bengkulu.

Baiyegunhi, LJS and Fraser, GCG (2010). Determinants of Household Poverty Dynamics in Rural Regions of the Eastern Cape Province, South Africa. Poster presented at the Joint $3^{\text {rd }}$ African Association of Agricultural Economists (AAAE) and $48^{\text {th }}$ Agricultural Economists Association of South Africa (AEASA) Conference, Cape Town, South Africa, September 19-23, 2010

Cahyono S. Andy, Nana Haryanti, Nur Ainun Jariyah dan Yongky Indrajaya. 2006. Faktor Penentu Kemiskinan Petani Penyadap Getah Pinus di desa Somagede, Kebumen, Jawa Tengah. Jurnal Penelitian Sosial dan Ekonomi Kehutanan. Vol. 3, No.2, Juni Tahun 2006.

Gounder, Neelesh (2013), Correlates of poverty in Fiji, International Journal of Social Economics, 40 (10): 923 938.

http:/ / dx.doi.org/10.1108/IJSE2012-0067

Nasir M., Saichudin dan Mauliar. (2008). Analisis Faktor-Faktor Yang Mempengaruhi Kemiskinan Rumah Tangga Di Kabupaten Purworejo. Jurnal Eksekutif Vol.5 No.4

Sajogyo, (1987). Ekologi Pedesaan, Sebuah Bunga Rampai, Penerbit Rajawali Pers, Jakarta.

Wiyanto, Hadi, Ketut Sukiyono, \& Basuki Sigit Priyono. (2014). Sebaran, Probabilitas Dan Faktor-Faktor Yang Mempengaruhi Probabilitas Terjadinya Kemiskinan Petani Sayuran Di Kecamatan Sindang Dataran Kabupaten Rejang Lebong. AGRISEP 13(1): $15 \quad-\quad 34$. DOI: https://doi.org/10.31186/agr isep.13.1.15-34

Yufi Halimah Sa'diyah,Fitrie Arianti. 2012. Analisis Kemiskinan Rumah Tangga Melalui Faktor-Faktor Yang Mempengaruhinya Di Kecamatan Tugu Kota Semarang. Accessed from http://ejournals1.undip.ac.id/index.php. 